\title{
Second messenger involvement in differentiation of the entomopathogenic fungus Metarhizium anisopliae
}

\author{
R. J. St Leger, ${ }^{*}$ T. M. Butt, R. C. Staples and D. W. Roberts \\ Boyce Thompson Institute for Plant Research, Tower Road, Cornell University, Ithaca, NY 14853 USA
}

(Received 22 December 1989; revised 1 May 1990; accepted 4 May 1990)

\begin{abstract}
The conidial germling of Metarhizium anisopliae produces an appressorium upon contact with a hard hydrophobic surface. We have conducted an investigation into how this entomopathogen mediates intracellularly the inductive signal to shift from polarized germ-tube growth to non-polarized appressorial growth. During sporulation, conidia accumulated ${ }^{45} \mathrm{Ca}^{2+}$ but there was no evidence for a gradient of $\mathrm{Ca}^{2+}$ in the spore which could establish the initial polarity. Calmodulin, however, was localized at the poles of the conidia, near the site of germ-tube emergence. Exposing conidia to $\mathrm{Ca}^{2+}$ deprivation or calmodulin antagonists inhibited germination and polar growth. Disruption of $\mathrm{Ca}^{2+}$ gradients by ionophoresis did not prevent germination but caused the multiple emergence of branched germ-tubes from conidia. These findings indicate that $\mathrm{Ca}^{2+}$ plays a fundamental role in establishing the dominance of apical growth. Although an external source of $\mathrm{Ca}^{2+}$ is not required for appressorium formation, germlings producing appressoria took up ${ }^{45} \mathrm{Ca}^{2+}$ when available. The ${ }^{45} \mathrm{Ca}^{2+}$ accumulated in the cell wall, plasma membrane and organelles suggesting that these may function as $\mathrm{Ca}^{2+}$ stores for $\mathrm{Ca}^{2+}$-stimulated exocytosis of cellwall materials. Mitochondria and vacuoles sequestered ${ }^{45} \mathrm{Ca}^{2+}$ indicating that they play a role in maintaining low cytoplasmic concentrations of ${ }^{45} \mathrm{Ca}^{2+}$ consistent with the reorganization of the cytoskeleton required for appressorial growth. Several $\mathrm{Ca}^{2+}$-binding proteins in appressoria may provide an energy-independent component of $\mathrm{Ca}^{2+}$ buffering in the cytoplasm. The results indicate that the apical $\mathrm{Ca}^{2+}$ gradient is disrupted during differentiation and subsequent differential $\mathrm{Ca}^{2+}$ redistribution in the cell enlargement zone coincides with germtube swelling. cAMP may also be involved by potentiating the effects of small changes in $\mathrm{Ca}^{2+}$ concentration and stimulating exocytosis of mucus components required for adhesion, which is a prerequisite for differentiation.
\end{abstract}

\section{Introduction}

Fungal hyphae are highly polarized structures that extend by the fusion of secretory vesicles with the plasma membrane of the hyphal apex. The rapidly extending tip is protected from the effects of the internal hydrostatic pressure which supplies the driving force for forward expansion by a thin cell wall supported by the actin cytoskeleton. During extension, new cell wall is displaced to the side walls and becomes hardened (secondary wall formation) by chemical cross-linking of wall components forming a structure rigid enough to with-

Abbreviations: $\mathrm{Br}-\mathrm{A} 23187$, 4-bromo-A23187; CaM, calmodulin; CTC, chlorotetracycline; DAPI, 4',6-diamidino-2-phenylindole; DCCD, $N, N^{\prime}$-dicyclohexylcarbodiimide; H-8, N(2-methylamino)ethyl-5-isoquinolinesulphonamide dihydrochloride; IBTX, 3-isobutyl1-methylxanthine; Sp-(cAMPS), adenosine $3^{\prime}: 5^{\prime}$-monophosphothiate, cyclic Sp-isomer; W-5, N-(6-aminohexyl)-1-naphthalenesulphonamide; YEM, yeast extract medium. stand turgor pressure (Jackson \& Heath, 1989; Wessels, 1986). The polarized mode of extension is manifested in many physiological features including the distribution of cytoskeletal elements and organelles (Jackson \& Heath, 1989; McKerracher \& Heath, 1987), the chemical composition and distribution of ions (Wessels, 1986) and consequently the electrical characteristics of the organism (Takeuchi et al., 1988). A model has been proposed to account for polarity in tip-growing systems in which $\mathrm{Ca}^{2+}$ plays a major role in the control of both vesicle fusion and the plasticity of the tip (Picton \& Steer, 1982).

By contrast to tip-growth, the branching process and other differentiation events occurring in fungi are poorly understood. Fungi respond morphologically to a very wide array of physical and chemical signals including touch, light, pheromones and nutrients. The mode of signal reception is poorly understood except in Dictyostelium where a complex transmembrane system for cAMP has been elucidated (Gerisch, 1987). Germ-tubes of the entomopathogenic fungus Metarhizium anisopliae are 
induced by contact with an appropriate surface to form terminal swellings (appressoria) in which a reduction in apical elongation is accompanied by an apparent collapse of polarity. Appressoria play key structural and functional roles in the entomopathogenicity of Metarhizium (St Leger et al., 1987, 1989a, b; Zacharuk, 1970). Appressoria are a major site of adhesion of the germling to the host and may provide a fulcrum for mechanical pressure exerted by infection pegs. As active producers of cuticle-degrading enzymes they play a crucial, if not exclusive role, in establishing a nutritional relationship with the host (Goettel et al., 1989; St Leger et al., 1987, $1989 \mathrm{~b}$ ). In contrast to germination, differentiation of infection structures by Metarhizium occurs only in response to specific host-related stimuli (a hard hydrophobic surface and low levels of complex nitrogenous nutrients) (St Leger et al., 1989a, c), and as such Metarhizium can serve as a useful model system for understanding signal transduction and the control of growth and morphological differentiation in a fungus.

Signal reception for cell differentiation probably occurs soon after the second nuclear division since inhibition of synthesis of DNA or RNA prior to this event prevents appressorium formation (St Leger $e t$ al., $1989 a$ ). The pathway of signal transduction of appressoria may involve a localized change in transmembrane potential produced by deformation of the plastic hyphal tip (St Leger et al., 1990a). Germlings possess both a $\mathrm{Ca}^{2+}$-dependent and a possible cAMP-dependent protein kinase activity suitable for signal mediation; the latter activity is associated with plasma membranes. Both types of kinase possess a large number of endogenous substrates (St Leger et al., 1990b). Plasma membranes also contain a group of guanine-nucleotidebinding proteins suited to be coupling factors for transmembrane signal transduction (St Leger et al., $1989 d$ ), a membrane-bound protein tyrosine kinase (St Leger et al., 1989c), a phosphoprotein phosphatase (St Leger et al., 1990b) and adenylate cyclase activity apparently involved in transmembrane signalling reactions, since mechanical or chemical treatments which stress the fungus or depolarize the plasma membrane cause rapid increases in intracellular levels of cAMP (St Leger et al., 1990b). As in animal and plant systems, exocytosis requires the presence of $\mathrm{Ca}^{2+}$ (St Leger et al., 1989c). These discoveries suggest a mechanism for a signal response by which an external stimulus is converted into intracellular second messengers, messenger-dependent regulatory phosphorylation activities, and finally to cell response. In the work presented here compounds that affect signalling and phosphorylation were used in order to test this conceptual framework with regard to polar growth and appressorium formation by Metarhizium.

\section{Methods}

Organism and growth. The fungal isolate (Metarhizium anisopliae ME1) and culture media were described by St Leger et al. (1987). Germination experiments and studies of differentiation in the presence of inhibitors were done in yeast extract medium (YEM, $0.0125 \% \mathrm{w} / \mathrm{v}$ ) (St Leger et al., 1989d).

Chemicals. ${ }^{125} \mathrm{I}-\mathrm{L}$ abelled $\mathrm{CaM}$ and ${ }^{45} \mathrm{Ca}^{2+}$ in an aqueous solution of $\mathrm{CaCl}_{2}$ [specific activity about $15 \mathrm{mCi} \mathrm{mg}^{-1}\left(555 \mathrm{MBq} \mathrm{mg}^{-1}\right)$ ] were from NEN. H-8 was from Seikagaku America Inc. (Sp)-cAMPS was from Boehringer Mannheim. Novozym 234 was from Novo Biolabs. Yeast extract was from Difco. Other chemicals were from Sigma.

Cyclic AMP content in differentiated germlings. Conidia suspended in YEM were germinated in $13.5 \mathrm{~cm}$ polystyrene dishes. After various periods, the cultures were harvested after pouring off the supernatant and washing the Petri dish bottom by stirring with distilled water $(1 \mathrm{~min})$. Ice-cold $5 \%(\mathrm{w} / \mathrm{v})$ trichloroacetic acid (TCA) $(5 \mathrm{ml})$ was added to a single dish, and the adherent germlings were scraped off. The TCA was then transferred sequentially to two other dishes and the mycelia were homogenized $(1 \mathrm{~min})$ using a motor-driven $(\sim 1100$ r.p.m. $)$ Teflon pestle and then extracted for a further $30 \mathrm{~min}$ at $0^{\circ} \mathrm{C}$. In this way germlings from 15 dishes were pooled into five aliquots for assay. All subsequent steps were as described for conidia and mycelia (St Leger $e t$ al., 1990b)

Localization of CaM. Conidia or germlings growing on polystyrene were fixed in $3.7 \%(\mathrm{v} / \mathrm{v})$ formalin for $60 \mathrm{~min}$, rinsed in sodium phosphate buffer $(0.1 \mathrm{M}, \mathrm{pH} 7)$ and in $0.4 \mathrm{M}$-mannitol (pH 5.5), treated with $0.2 \%$ Novozym in $0.4 \mathrm{M}$-mannitol $(30 \mathrm{~min})$, rinsed in buffer and further permeabilized with $0 \cdot 1 \%$ Triton X-100 (30 min). After washing with buffer the preparations were incubated for $10 \mathrm{~min}$ in an aqueous solution of the fluorescent CaM probe W-5 $(35 \mu \mathrm{M})$ before visualization using a Zeiss microscope equipped with a $365 \mathrm{~nm}$ excitation filter and $395 \mathrm{~nm}$ dichroic mirror.

Uptake of ${ }^{45} \mathrm{Ca}^{2+}$. Aliquots $(2 \mathrm{ml})$ of a conidial suspension $\left(1 \times 10^{6}\right.$ spores $\left.\mathrm{ml}^{-1}\right)$ in YEM $(0.0125 \%)$ were incubated at $27^{\circ} \mathrm{C}$ in $5.5 \mathrm{~cm}$ Petri dishes until about $50 \%$ of the germlings had undergone two mitotic divisions (after about $14 \mathrm{~h}$ ). Cultures were supplemented with ${ }^{45} \mathrm{Ca}^{2+}$ $\left[3 \mu \mathrm{Ci} \mathrm{ml}^{-1}\left(111 \mathrm{kBq} \mathrm{ml}^{-1}\right)\right]$ and following a further incubation period $(10 \mathrm{~h})$, the supernatant was poured off from each dish and the Petri dish bottom was washed by stirring with three changes of $10 \mathrm{mM}-\mathrm{Tris} / \mathrm{HCl}$ buffer $(\mathrm{pH} \mathrm{7.2)}(3 \times 3 \mathrm{ml}, 2 \mathrm{~min}$ each). The Petri dishes were then extracted for 20 min with fresh $\mathrm{Ca}^{2+}$-free Tris buffer or buffer supplemented either with $\mathrm{CaCl}_{2}(5 \mathrm{mM})$ or EGTA $(5 \mathrm{mM})$. Following extraction the Petri dishes were washed with two changes of Tris buffer and the adherent germlings under buffer were scraped off the dish bottom with a rubber policeman. The cells were filtered on a glassfibre (Whatman GF/C) disc and washed twice with Tris buffer at $0^{\circ} \mathrm{C}$. The filters were dried and the radioactivity was determined with a scintillation counter. The amount of ${ }^{45} \mathrm{Ca}^{2+}$ binding to cells extracted with unsupplemented Tris buffer was taken to represent the total bound ${ }^{45} \mathrm{Ca}^{2+}$. The extent of decline in ${ }^{45} \mathrm{Ca}^{2+}$ binding after cells were extracted with Tris buffer supplemented with $\mathrm{CaCl}_{2}$ or EGTA was taken as a measure of surface-bound ${ }^{45} \mathrm{Ca}^{2+}$ (after correction for background radioactivity on Petri dishes determined using dishes incubated with ${ }^{45} \mathrm{Ca}^{2+}$-labelled YEM minus spores).

$\mathrm{Ca}^{2+}$ uptake during sporulation was studied using conidia obtained from a 12-d-old culture grown on Sabouraud dextrose agar supplemented with ${ }^{45} \mathrm{Ca}^{2+}\left(3 \mu \mathrm{Ci} \mathrm{ml}^{-1}\right)$. Samples $(200 \mu 1)$ of a conidial suspension $\left(3 \times 10^{6} \mathrm{ml}^{-1}\right)$ were spotted directly onto glassfibre discs. The conidia were washed $(5 \times 5 \mathrm{ml})$ with Tris buffer. The conidia were further washed in Tris buffer $(3 \times 5 \mathrm{ml})$ or Tris buffer supplemented with unlabelled $\mathrm{CaCl}_{2}(5 \mathrm{~mm})$ to remove surface-bound label. Residual cell-bound ${ }^{45} \mathrm{Ca}^{2+}$ was determined as described above. 
Localization of $\mathrm{Ca}^{2+}$ within the cell. Conidia $\left(1 \times 10^{6} \mathrm{ml}^{-1}\right)$ were germinated for $32 \mathrm{~h}$ in YEM $(0.05 \%$, w/v) shake cultures $(75$ r.p.m. $)$ in the presence of ${ }^{45} \mathrm{Ca}^{2+}\left(3 \mu \mathrm{Ci} \mathrm{ml}^{-1}\right)$. Mycelia were harvested by filtration (Whatman no. 1 paper), shaken for $30 \mathrm{~min}$ at $25^{\circ} \mathrm{C}$ in buffer (10 mM-Tris/HCl, $1 \mathrm{~mm}$-EGTA), centrifuged $(4000 \mathrm{~g}, 10 \mathrm{~min})$ and the pellet washed in $1 \mathrm{M}$-sorbitol. Protoplasts were obtained by suspending mycelia in buffer ( $1.2 \mathrm{M}$-sorbitol, $10 \mathrm{~mm}$-Tris $/ \mathrm{HCl}, \mathrm{pH} 7)$ supplemented with $0.8 \%$ Novozym 234 (Goettel et al., 1990). Protoplasts were separated from cellular debris by filtration through cheesecloth and a $20 \mu \mathrm{m}$ plastic screen. Following centrifugation $(2000 \mathrm{~g}, 10 \mathrm{~min})$ the protoplast pellet was washed three times with buffer. Protoplasts were suspended in $5 \mathrm{ml} 330 \mathrm{~mm}$-sucrose containing BSA $(0-3 \%$, w/w) $(\mathrm{pH} 7 \cdot 1)$ and disrupted by sonication at $4{ }^{\circ} \mathrm{C}$. The homogenate was centrifuged $(1000 \mathrm{~g}, 10 \mathrm{~min})$ and a mitochondrial fraction was obtained from the supernatant by a further centrifugation $(15000 \mathrm{~g}, 30 \mathrm{~min})$. The $15000 \mathrm{~g}$ supernatants were recentrifuged $(12000 \mathrm{~g}, 30 \mathrm{~min})$ to remove remaining mitochondria, and the supernatants centrifuged a final time at $40000 \mathrm{~g}(40 \mathrm{~min})$ to pellet plasma membranes (Bowman \& Bowman, 1988). Mitochondrial and plasma-membrane pellets were suspended in $0.6 \mathrm{ml} 10 \mathrm{~mm}$-Tris/ $\mathrm{HCl}$ buffer (pH 7.5) containing $1 \mathrm{~mm}$-EGTA. The radioactivity in supernatants and pellets was determined using a scintillation counter.

Isolation of organelles for ${ }^{45} \mathrm{Ca}^{2+}$ influx studies. Mitochondria and vacuoles were isolated from mycelia from $32 \mathrm{~h} \mathrm{SDB}$ cultures using the bead-beater procedure of Bowman \& Bowman (1988). Mitochondria were separated from vacuoles by sucrose gradient centrifugation (Bowman \& Bowman, 1988). Immediately thereafter the fractions were assayed for protein content (Bradford, 1976) and for $\mathrm{Ca}^{2+}$ transport activity.

$\mathrm{Ca}^{2+}$ uptake by isolated organelles. [Modified from Cornelius \& Nakashima (1987) and Uchida et al. (1988).] ${ }^{45} \mathrm{Ca}^{2+}$ uptake by membrane fractions was measured at $22^{\circ} \mathrm{C}$ as follows. (1) For mitochondria the reaction mixture $(100 \mu \mathrm{l})$ contained $5 \mathrm{mM}$-PIPES/Tris buffer (pH 7.8), $5 \mathrm{mM}-\mathrm{Na}_{2} \mathrm{ATP}, 5 \mathrm{mM}-\mathrm{MgSO}_{4}, 50 \mathrm{mM}-\mathrm{KCl}$, $5 \mathrm{mM}-\mathrm{K}_{2} \mathrm{HPO}_{4}, 1 \mathrm{mM}-\mathrm{Na}_{3} \mathrm{VO}_{4}$ (to inhibit residual plasma-membrane ATPase) and $0.2 \mathrm{~mm}-\mathrm{CaCl}_{2}$ [containing $0.25 \mu \mathrm{Ci}(9.25 \mathrm{kBq}){ }^{45} \mathrm{Ca}^{2+}$ ]. Uptake was initiated by adding $20 \mu \mathrm{g}$ of mitochondria (determined by protein content). (2) For vacuoles the reaction mixture $(100 \mu \mathrm{l})$ contained $5 \mathrm{~mm}$-PIPES/Tris buffer (pH 7.4), $5 \mathrm{~mm}-\mathrm{Na}_{2} \mathrm{ATP}, 5 \mathrm{~mm}$ $\mathrm{MgCl}_{2}, 1 \mathrm{~mm}-\mathrm{Na}_{3} \mathrm{VO}_{4}$ and $0.4 \mathrm{mM}-\mathrm{CaCl}_{2}$ (containing $0.25 \mu \mathrm{Ci}$ ${ }^{4} \mathrm{Ca}^{2+}$ ). Uptake was initiated by adding $20 \mu \mathrm{g}$ of vacuole membranes. Uptake was stopped after $10 \mathrm{~min}$ by collecting mitochondria or vacuoles onto $0.45 \mu \mathrm{m}$ membrane filters and rapidly washing with two $5 \mathrm{ml}$ aliquots of ice-cold buffer minus ${ }^{45} \mathrm{Ca}^{2+}$ and ATP. The filters were incubated in washing buffer for $30 \mathrm{~min}$ under vacuum prior to use Radioactivity was determined in a liquid scintillation counter. Zero time controls were used as blanks.

Miscellaneous. Nuclei and cell walls were stained using DAPI and Uvitex, respectively (St Leger et al., 1989a). The distribution of intracellular membranes was assessed with 3,3'-dihexylocarbocyanine iodide (Butt et al., 1989). CTC staining of $\mathrm{Ca}^{2+}$ was done as described in Butt et al. (1989). CaM levels were determined with a CaM-specific radioimmunoassay (St Leger et al., 1989c). ${ }^{125}$ I-Labelled CaM binding was done as described by St Leger et al. $(1990 \mathrm{~b})$. Proteins were processed for and subjected to SDS-PAGE as described by St Leger $e t$ al. $(1989 b)$. The ${ }^{45} \mathrm{Ca}^{2+}$ overlay method of Maruyama et al. (1984) was used to detect $\mathrm{Ca}^{2+}$-binding proteins after separation by SDS-PAGE and transfer to nitrocellulose filters.

Antagonists were added to cultures from stock solutions in YEM. Ionophores were added from stock solutions in ethanol. The final concentration of ethanol was $\leq 0.04 \%$ which had no effect on differentiation.

\section{Results}

Conidia germinating in $0.0125 \%$ YEM usually produced a single germ-tube slightly lateral to one of the poles. Non-differentiated Metarhizium germlings grow by apical extension of the hyphal tip until induced to undergo cell differentiation by contact with a suitable substrate (e.g. polystyrene) when germlings typically produced a terminal swelling (appressorium; Fig. $1 a$ ) the first in a series of structures normally involved in infection of a host.

Prior to germination, localized components of the cytoplasm must exist to orient the growth axis of the germling and initiate polarized outgrowth of the germtube. Potentially, localized cytoplasmic $\mathrm{Ca}^{2+}$ may orient the growth axis. However, most germinating conidia of Metarhizium were labelled uniformly with CTC, and less than $10 \%$ of spores displayed a non-uniform distribution of fluorescent intensity that would indicate a gradient of $\mathrm{Ca}^{2+}$ within the cell that might relate to polarization. Disruption of minute or otherwise undetectable $\mathrm{Ca}^{2+}$ gradients in conidia with high concentrations of the calcium ionophore Br-A23187 $(50 \mu \mathrm{M})$ did not prevent polar outgrowth of germ-tubes, although germ-tubes were shorter and broader at the base which fluoresced brightly with Uvitex in the presence of ionophore (Fig. $1 b$, Table 1). At a lower concentration $(10 \mu \mathrm{M}) \mathrm{Br}$ A23187 increased the incidence of bipolar germination from $4 \%$ (in YEM controls) to $12 \%\left(\chi^{2}=11.9, P<0.01\right.$ ). Over $80 \%$ of the conidia demonstrating bipolar germination produced germ-tubes at opposite poles of the spore (Fig. 1c), which suggested that bipolarity did not reflect a disruption of the growth axis. Usually, following nuclear division, only one of the germ-tubes received a daughter nucleus; the second smaller germ-tube remained anucleate and non-septate. As expected from previous results (St Leger et al., 1989c) germination was normal in a $\mathrm{Ca}^{2+}$-free medium (2 mM-EGTA) but was much reduced or abnormal with formation of a short bulbous germling when intracellular $\mathrm{Ca}^{2+}$ was depleted $(\mathrm{Br}-$ A23187 + 2 mM-EGTA) (Fig. $1 d$ ). In addition, while $50 \mu \mathrm{M}-\mathrm{Br}-\mathrm{A} 23187$ (minus EGTA) reduced germination (i.e. the morphological expression of polarity) by only $10-15 \%$, elongation of germ-tubes was reduced by $30 \%$ after $24 \mathrm{~h}$ (Table 1) and by over $70 \%$ after $30 \mathrm{~h}$ indicating that regardless of its role in fixing the growth axis, intracellular $\mathrm{Ca}^{2+}$ is important for the maintenance of rapid tip growth.

Membrane-associated $\mathrm{Ca}^{2+}$ in germlings was localized by CTC fluorescence. Intracellular $\mathrm{Ca}^{2+}$ may be demonstrated by weakly fluorescing punctate material observed in the cytoplasm of germlings. Unfortunately, because of the rapid bleaching of fluorescence (within seconds), it was not possible to identify the organelles responsible. A 


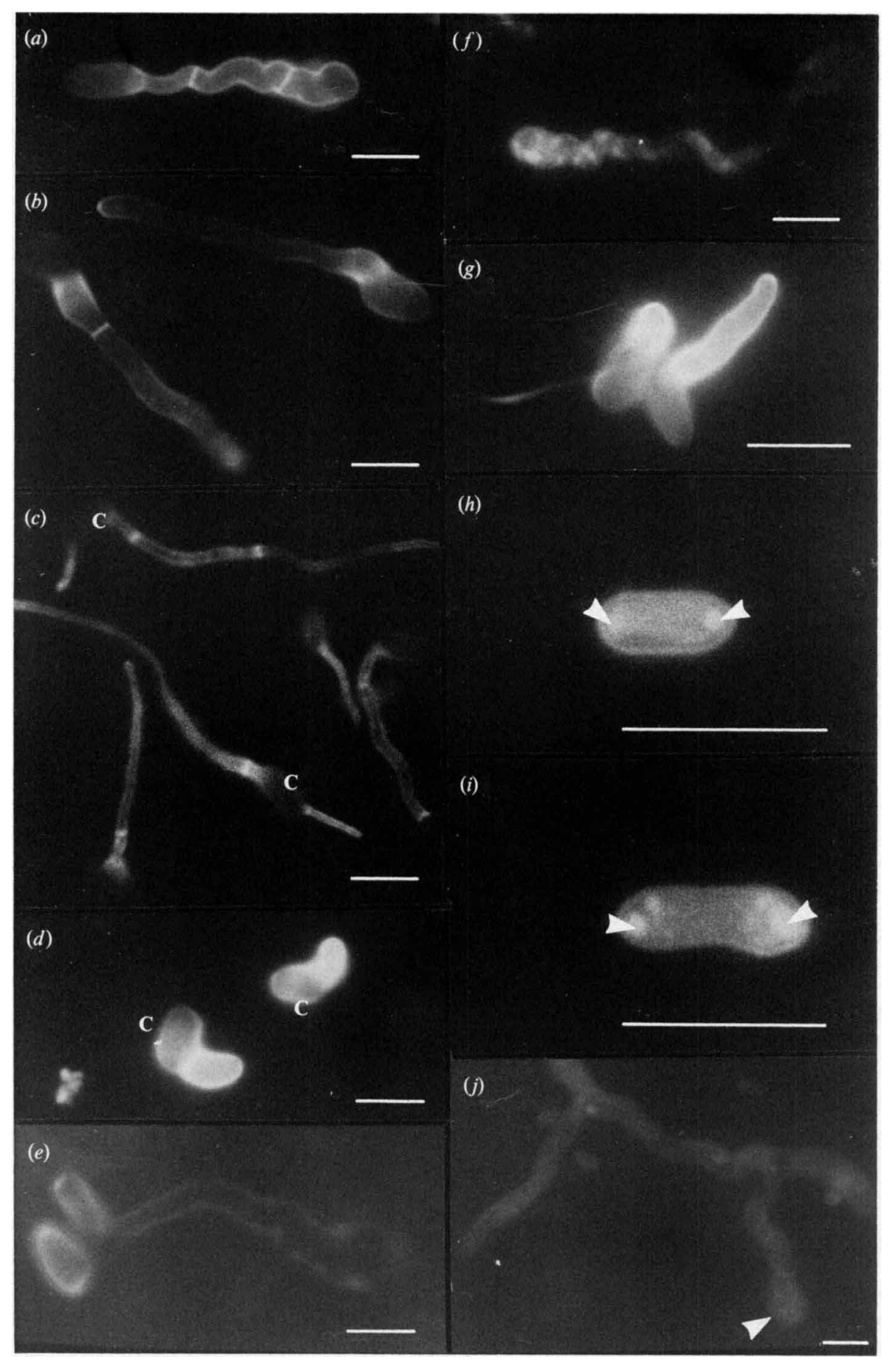

Fig. 1. Fluorescence micrographs of Metarhizium germinated in YEM $(0.0125 \%)$ on polystyrene for $24 \mathrm{~h}$ (unless stated otherwise). (a) Germling stained with Uvitex to show terminal appressorium. $(b, c)$ Germlings grown with Br-A23187 and stained with Uvitex to show bulbous swelling at base of germ-tube $(b ; 50 \mu \mathrm{M}-\mathrm{Br}-\mathrm{A} 23187)$ or bipolar germination $(c ; 10 \mu \mathrm{M}-\mathrm{Br}-\mathrm{A} 23187)$. (d) Formation of short

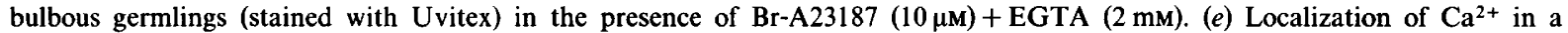
differentiated germling by CTC fluorescence. $(f)$ Distribution of intracellular membranes assessed with 3,3-dihexylocarbocyanine iodide (note differential staining of appressoria). $(\mathrm{g}$ ) Formation of short bulbous germlings (stained with Uvitex) in the presence of $\mathrm{R} 24571(3 \mu \mathrm{M}) .(h, i) \mathrm{W}$-5-associated fluorescence in a permeabilized dry conidium $(h)$ and a conidium presoaked in YEM $(0.0125 \%)$ for $6 \mathrm{~h}(i)$; arrows indicate localization of $\mathrm{CaM}$ at conidial poles. $(j) \mathrm{W}$-5-associated fluorescence of a germling grown for $40 \mathrm{~h}$ in $0.02 \%$ YEM; arrow indicates a subterminal appressorium. Bars, $10 \mu \mathrm{m}$; $\mathrm{C}$, conidium. 
Table 1. Effects of Br-A23187 and second messengers on the growth of Metarhizium

Conidia were incubated for $24 \mathrm{~h}$ with inhibitor in YEM.

\begin{tabular}{|c|c|c|c|c|c|}
\hline $\begin{array}{c}\mathrm{Br}-\mathrm{A} 23187 \\
(\mu \mathrm{M})\end{array}$ & Addition & $\begin{array}{l}\text { Percentage } \\
\text { germination }\end{array}$ & $\begin{array}{c}\text { Mean length }( \pm S E) \text { of } \\
\text { germ-tube }(\mu M)\end{array}$ & $\begin{array}{c}\text { Percentage } \\
\text { differentiation }\end{array}$ & $\begin{array}{l}\text { Mean no. of } \\
\text { growing } \\
\text { points per } \\
\text { germ-tube }\end{array}$ \\
\hline 0 & 0 & $>95$ & $65 \pm 7$ & 68 & 1.04 \\
\hline 0 & EGTA (2 mM) & $>95$ & $61 \pm 8$ & 62 & 1.04 \\
\hline 3 & 0 & $>95$ & $60 \pm 6$ & 63 & $1 \cdot 012$ \\
\hline 5 & 0 & $>95$ & $58 \pm 6$ & 56 & 1.62 \\
\hline 10 & 0 & $>95$ & $52 \pm 5$ & 21 & 1.83 \\
\hline 50 & $\mathbf{0}$ & 81 & $45 \pm 6$ & 0 & $1 \cdot 10$ \\
\hline 5 & EGTA (2 mM) & 68 & $11 \pm 2$ & 0 & $1 \cdot 0$ \\
\hline $\mathbf{0}$ & $\mathrm{CaCl}_{2}(0 \cdot 1 \mathrm{mM})$ & $>95$ & $68 \pm 9$ & 75 & $1 \cdot 22$ \\
\hline 5 & $\mathrm{CaCl}_{2}(0.1 \mathrm{mM})$ & $>95$ & $76 \pm 7$ & 61 & $1 \cdot 21$ \\
\hline $\mathbf{0}$ & $\mathrm{CaCl}_{2}(1 \mathrm{~mm})$ & $>95$ & $76 \pm 6$ & 54 & $1 \cdot 24$ \\
\hline 5 & $\mathrm{CaCl}_{2}(1 \mathrm{~mm})$ & $>95$ & $96 \pm 8$ & 0 & $1 \cdot 13$ \\
\hline 0 & $\mathrm{CaCl}_{2}(10 \mathrm{mM})$ & 92 & $74 \pm 7$ & 52 & $1 \cdot 12$ \\
\hline 5 & $\mathrm{CaCl}_{2}(10 \mathrm{mM})$ & 93 & $81 \pm 5$ & 0 & 1.05 \\
\hline 0 & $\mathrm{CaCl}_{2}(100 \mathrm{~mm})$ & 82 & $60 \pm 10$ & 5 & $1 \cdot 06$ \\
\hline 5 & $\mathrm{CaCl}_{2}(100 \mathrm{mM})$ & 68 & $46 \pm 8$ & 0 & $1 \cdot 04$ \\
\hline 5 & $\mathrm{MgCl}_{2}(1 \mathrm{~mm})$ & $>95$ & $75 \pm 4$ & 4 & $1 \cdot 20$ \\
\hline 5 & $\mathrm{MgCl}_{2}(10 \mathrm{mM})$ & $>95$ & $83 \pm 14$ & 0 & 1.04 \\
\hline 3 & cAMP (10 mM) & 92 & $48 \pm 3$ & $\mathbf{0}$ & $1 \cdot 86$ \\
\hline 3 & cGMP (10 mM) & 93 & $44 \pm 8$ & $\mathbf{0}$ & $1 \cdot 92$ \\
\hline 3 & (Sp)-cAMPS (1 mM) & 90 & $49 \pm 4$ & 0 & 1.73 \\
\hline 3 & IBTX (10 mM) & 94 & $47 \pm 3$ & 0 & $2 \cdot 18$ \\
\hline 3 & $\begin{array}{l}\mathrm{CaCl}_{2}(1 \mathrm{mM}) \\
+\mathrm{cAMP}(10 \mathrm{~mm})\end{array}$ & $>95$ & $82 \pm 7$ & 0 & 1.09 \\
\hline $\mathbf{0}$ & H-8 (1 mM) & $>95$ & $72 \pm 6$ & $\mathbf{0}$ & 1.04 \\
\hline 5 & H-8 (1 mM) & $>95$ & $70 \pm 4$ & $\mathbf{0}$ & 1.09 \\
\hline
\end{tabular}

diffuse and more permanent cortical staining (Fig. 1e) may reflect $\mathrm{Ca}^{2+}$ associated with the mucus, appressorial wall or the plasmalemma. As CTC fluorescence is affected by membrane density (Caswell, 1979), the distribution of intracellular membranes was assessed with 3,3'-dihexylocarbocyanine iodide (Butt et al., 1989). Preferential staining of appressoria (Fig. $1 f$ ) is indicative of the high density of endoplasmic reticulum and mitochondria these cells contain. However, fluorescence did not overlap with $\mathrm{Ca}^{2+}-\mathrm{CTC}$ fluorescence.

Recent studies indicate that the $\mathrm{Ca}^{2+}$-binding protein $\mathrm{CaM}$ is the regulator of $\mathrm{Ca}^{2+}$-dependent processes in Metarhizium conidia (St Leger et al., 1989c, 1990b). Consistent with this, CaM antagonists such as R24571 inhibit germination or produce a swollen germ-tube resembling that formed by $\mathrm{Ca}^{2+}$ depletion (Fig. 1 g). W5 , a specific fluorescent antagonist of $\mathrm{CaM}$ was used to localize CaM. W-5-associated fluorescence in permeabilized conidia was concentrated as spots at the very tips of the poles (Fig. 1 h). Presoaking spores in YEM $(0.0125 \%)$ for $6 \mathrm{~h}$ to swell them, an event that precedes normal germination, produced a more diffuse fluorescence, but the highest fluorescence intensity was still found in the region of the poles (Fig. 1 $i$ ). Growing hyphae and appressoria showed a weaker, more uniform fluores- cence (Fig. $1 j$ ). In treatments omitting permeabilization of conidia and germlings, hyphae were unstained except for a weak fluorescence at the periphery of cells. Thus, W-5 is not membrane permeable.

Germlings continued to produce high levels of appressoria in a $\mathrm{Ca}^{2+}$-free medium ( 2 mM EGTA) (Table 1) indicating that $\mathrm{Ca}^{2+}$ uptake is not necessary for signal mediation for appressorium formation. However, addition of $\mathrm{Ca}^{2+}\left(0 \cdot 1 \mathrm{mM}-\mathrm{CaCl}_{2}\right.$, Fig. $\left.2 a\right)$ increased differentiation frequency at $24 \mathrm{~h}$ from $68 \%$ (YEM alone) to $76 \%$ $\left(\chi^{2}=4.76, P<0.05\right)$. At higher concentrations, $\mathrm{Ca}^{2+}$ lowered differentiation frequency (Table 1) and increased the proportion of appressoria with abnormal morphologies. Thus, $\mathrm{CaCl}_{2}$ at $1 \mathrm{~mm}$ (Fig. $2 b$ ) and $10 \mathrm{~mm}$ (Fig. 2c) caused formation of narrow branched appressoria which were frequently subterminal or grew with a curved orientation and produced large amounts of mucus. $\mathrm{CaCl}_{2}$ at $100 \mathrm{mM}$ reduced polar growth and resulted in abnormally thin, frequently curved hyphae (Fig. $2 d-e$ ). Although mitotic division was not inhibited, large vacuoles (voids) in the cytoplasm were sometimes observed that were rarely seen in controls.

The effects of $\mathrm{Ca}^{2+}$ on differentiation were greatly potentiated by the presence of $\mathrm{Br}-\mathrm{A} 23187$. At high concentrations $(\geq 10 \mu \mathrm{M})$, the ionophore was an effective 


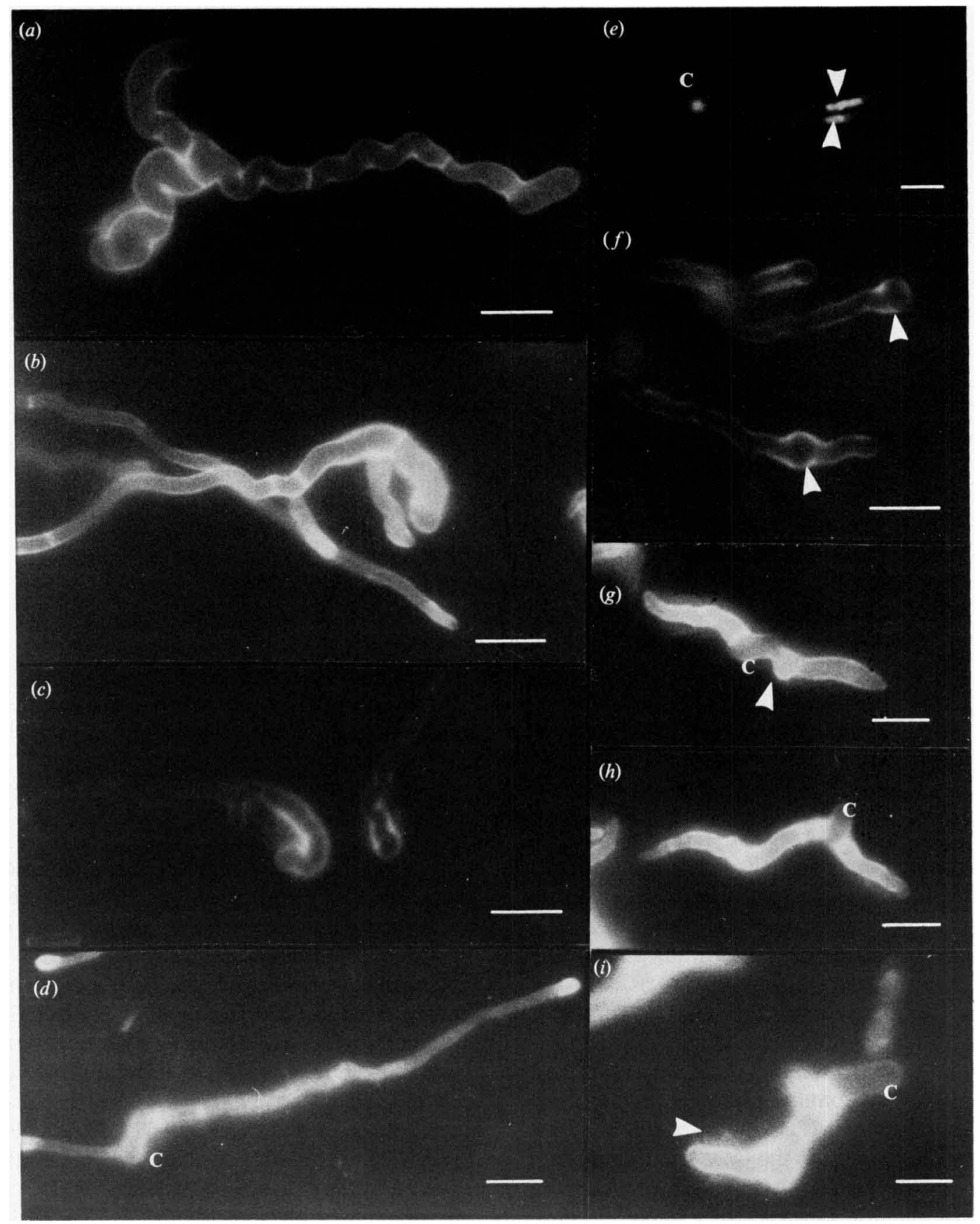

Fig. 2. Fluorescence micrographs of Metarhizium germinated in YEM $(0.0125 \%)$ on polystyrene for $24 \mathrm{~h}$. (a-d) Germlings stained with Uvitex to show behaviour in the presence of $(a) 0.1 \mathrm{mM}-\mathrm{CaCl}_{2},(b) 1 \mathrm{mM}-\mathrm{CaCl}_{2}$ (note thin branched appressorium), (c) $10 \mathrm{mM}^{-\mathrm{CaCl}}$ (note curvilinear thin appressorium) or $(d) 100 \mathrm{mM}-\mathrm{CaCl}_{2}$ (note reduced growth, twin hyphae and inhibition of appressorium formation). (e). DAPI staining of germling grown in $100 \mathrm{mM} \mathrm{CaCl}_{2}$ [note multiple nuclei (indicated by arrows) in a curved germ-tube] $(f)$ Uvitex staining of germling grown in $10 \mu \mathrm{M}-\mathrm{Br}-\mathrm{A} 23187$ (note local ballooning of germ-tubes indicated by arrows). (g-i) Uvitex staining of germlings grown in $3 \mu \mathrm{M}-\mathrm{Br}-\mathrm{A} 23187+10 \mathrm{mM}$-cAMP [note bipolar germination $(g, h)$, ballooning of germ-tube base (indicated by arrow) $(\mathrm{g})$, and broad irregularly-shaped germ tube-with mucus (indicated by arrow) $(i)]$. Bars, $10 \mu \mathrm{m}$; $\mathrm{C}$, conidium.

inhibitor of appressorium formation, particularly in the presence of EGTA (Table 1). By contrast, Br-A23187 stimulated side branching (Table 1). Also, in the presence of ionophore about $40 \%$ of germ-tubes had irregularly shaped cell walls and bulbous swellings along the hyphae apparently caused by periodic ballooning of the hyphal tips (Fig. $2 f$ ).

These effects may result from loss of intracellular $\mathrm{Ca}^{2+}$ 


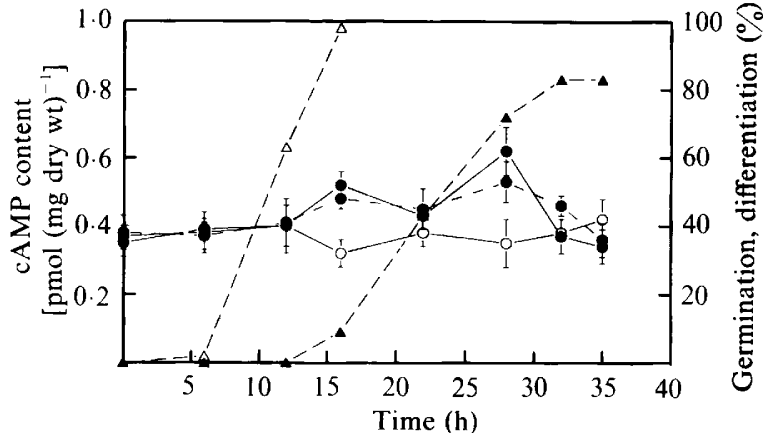

Fig. 3. Time course of changes in endogenous cAMP in germinating conidia producing non-differentiated germ-tubes $(O)$ and in germlings forming appressoria (O). Each experiment was repeated three times. Results with differentiating cells are from the two experiments which produced the most disparate results ( is the mean of five replicates \pm SE. The time course for germination $(\triangle)$ and production of appressoria $(\boldsymbol{A})$ is shown.

as application of ionophore simultaneously with exogenous $\mathrm{Ca}^{2+}\left(0.5 \mathrm{mM}-\mathrm{CaCl}_{2}\right)$ substantially increased polar growth (Table 1) resulting in long thin hyphae with smooth walls. The growing tips stained brightly with Uvitex indicative of plastic primary wall material, but differentiation of appressoria was entirely inhibited by an increased cytoplasmic $\mathrm{Ca}^{2+}$ concentration. Polar growth was stimulated to a lesser extent by $\mathrm{Mg}^{2+}$ plus A23187 or Br-A23187 (Table 1). However, addition of other divalent cations $\left(\mathrm{Ba}^{2+}, \mathrm{Zn}^{2+}\right.$ and $\left.\mathrm{Mn}^{2+}\right)$ with A23187 had no visible effects on germ-tube elongation or else they were toxic (data not presented). Above $1 \mathrm{~mm}$, $\mathrm{Ca}^{2+}$ was inhibitory to growth in the presence of ionophore (Table 1).

Levels of cAMP remained almost constant in nondifferentiated germlings (6-24 h, post-inoculation) at about $0.4 \pm 0.06 \mathrm{pmol}$ (mg dry $\mathrm{wt}^{-1}$, respectively. cAMP levels in differentiating germlings fluctuated but at a level higher than in non-differentiated cells (Fig. 3).

Application of cyclic nucleotides (cAMP, cGMP), (Sp)-cAMPS [a phosphodiesterase-resistant, membranepermeable activator of cAMP-dependent protein kinases (Rothermel et al., 1984)] and the cyclic nucleotide phosphodiesterase inhibitor IBTX were ineffective at altering growth and morphology at any concentration used $(0 \cdot 1-10 \mathrm{mM})$. However, when applied simultaneously with Br-A23187, they potentiated the effects of the ionophore (Table 1). Thus, although Br-A23187 at $3 \mu \mathrm{M}$ has little apparent effect on morphology by itself, when combined with either cAMP, cGMP or IBTX (all at $10 \mathrm{mM})$ or $(\mathrm{Sp})$-cAMPS $(1 \mathrm{mM})$ it resulted in frequent $(>30 \%)$ bipolar germination. In contrast to treatments with ionophore alone (Fig. 1 c), germ-tubes formed from any part of the spore and were usually septate (Fig. $2 g-i$ ). Increased synthesis of mucus induced by $\mathrm{Br}-\mathrm{A} 23187$ plus cAMP resulted in a high background with DAPI staining but careful focusing revealed that the germtubes were multinucleate even when a nucleus remained in the conidium. The most likely explanation for this is that cyclic nucleotide stimulates the conidial nucleus to undergo two mitotic divisions; in controls (YEM only) the single conidial nucleus typically divides once and only the daughter nucleus which enters the growing germ-tube divides again (St Leger et al., 1989a). Germlings that formed in the presence of Br-A23187 plus cAMP were short and often uniformly broad, so that distinguishable appressoria could not be observed. Occasionally, a balloon-like swelling formed from the conidia before the germling was successful in establishing polarized tip growth (Fig. $2 \mathrm{~g}$ ). Production of sidebranches on the short germ-tubes was also indicative of multiple attempts to form apices. The walls of the germlings fluoresced brightly with Uvitex, particularly in those regions which were irregularly shaped or swollen.

Application of exogenous $\mathrm{Ca}^{2+}$ counteracted the effects of ionophore plus cAMP as effectively as it overcame growth inhibition produced by treatment with the ionophore alone (Table 1). Thus, perturbation of the intracellular $\mathrm{Ca}^{2+}$ gradient is necessary before the effects of cAMP are expressed. Conversely, formation of sidebranches and appressoria by germlings is repressed by $\mathrm{H}-8$ [the $\mathrm{H}$-series inhibitor with the highest affinity for cyclic nucleotide dependent kinases (Hidaka \& Tanaka, 1987)] in the presence or absence of ionophore.

\section{$\mathrm{Ca}^{2+}-$ and CaM-binding proteins}

CaM levels (radioimmunoassay) in non-differentiated and differentiated germlings were not significantly different at $3.2 \pm 0.68$ and $3.7 \pm 0.45 \mu \mathrm{g}$ rate equivalent $\mathrm{CaM}$ (mg total protein $)^{-1}$, respectively. Several prominent target proteins were found in differentiated germlings. However, there were no reproducible differences with the ${ }^{125} \mathrm{I}$-labelled CaM-binding proteins detected in ungerminated germlings (data not presented). The autoradiograph in Fig. 4 shows the binding of ${ }^{45} \mathrm{Ca}^{2+}$ to proteins from differentiated cells. Electrophoresis was done in the presence of $\mathrm{CaCl}_{2}(5 \mathrm{mM})$ or EGTA $(5 \mathrm{~mm})$ since some $\mathrm{Ca}^{2+}$-binding proteins (e.g. $\mathrm{CaM}$ ) have increased migration rates in the presence of $\mathrm{Ca}^{2+}$. Two proteins migrated faster in the presence of $\mathrm{Ca}^{2+}$; other $\mathrm{Ca}^{2+}$-binding proteins co-migrated with proteins incubated with EGTA.

\section{$\mathrm{Ca}^{2+}$ uptake and distribution in Metarhizium}

${ }^{45} \mathrm{Ca}^{2+}$ accumulated in conidia when mycelia sporulated on Sabouraud dextrose agar containing the 


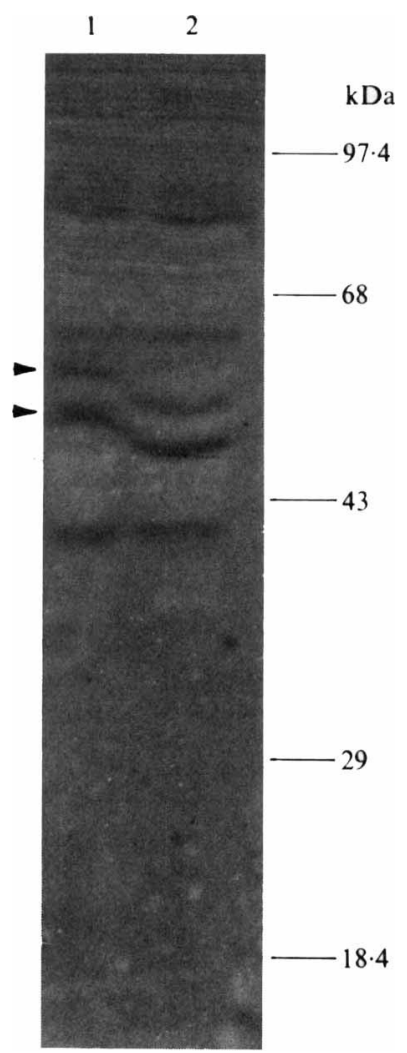

Fig. 4. $\mathrm{Ca}^{2+}$-binding proteins in differentiated germlings of Metarhizium. Proteins were separated by SDS-PAGE in the presence of $5 \mathrm{mM}$ EGTA (lane 1) or $5 \mathrm{mM}-\mathrm{CaCl}_{2}$ (lane 2), transferred to a $0.2 \mu \mathrm{m}$ nitrocellulose membrane and exposed to ${ }^{45} \mathrm{Ca}^{2+}\left(1 \mu \mathrm{Ci} \mathrm{ml}^{-1}\right)$ in the presence of $60 \mathrm{~mm}-\mathrm{KCl}$ and $5 \mathrm{~mm}-\mathrm{MgCl}_{2}$. Arrowheads indicate proteins with increased mobility in the presence of $\mathrm{Ca}^{2+}$.

isotope. Washing conidia in Tris buffer plus unlabelled $\mathrm{CaCl}_{2} \quad$ (5 mM) lowered cell-bound ${ }^{45} \mathrm{Ca}^{2+}$ to $84000 \pm 9000$ c.p.m. per $6 \times 10^{5}$ conidia compared with $102000 \pm 6000$ c.p.m. per $6 \times 10^{5}$ conidia with Tris buffer alone, indicating that a component (about $18 \%$ ) of the ${ }^{45} \mathrm{Ca}^{2+}$ was surface-bound. ${ }^{45} \mathrm{Ca}^{2+}$ uptake by germlings was studied during the period (14-24 h postinoculation) of appressorium formation (Table 2). During differentiation, appressoria took up high levels of ${ }^{45} \mathrm{Ca}^{2+}$. A proportion (about $40 \%$ ) of the ${ }^{45} \mathrm{Ca}^{2+}$ was removed by treatment with EGTA and was exchangeable with an excess of unlabelled $\mathrm{Ca}^{2+}$, consistent with an accumulation of $\mathrm{Ca}^{2+}$ by the outer surface of the plasma membrane and the cell wall.

The cellular distribution of ${ }^{45} \mathrm{Ca}^{2+}$ was studied by cell fractionation and subsequent analysis of ${ }^{45} \mathrm{Ca}^{2+}$ in the cell fractions (Table 3). A decrease in the radioactivity of the particulate fraction occurred after cell wall digestion indicating the presence of $\mathrm{Ca}^{2+}$ in the cell walls. This decrease may have been underestimated due to redistribution of wall-bound $\mathrm{Ca}^{2+}$ following digestion. The association of ${ }^{45} \mathrm{Ca}^{2+}$ with the sedimented mitochon-
Table 2. ${ }^{45} \mathrm{Ca}^{2+}$ remaining bound to differentiated germlings after extraction of cell-wall-bound ${ }^{45} \mathrm{Ca}^{2+}$ with unlabelled $\mathrm{CaCl}_{2}$ or EGTA

The values represent the amount of ${ }^{45} \mathrm{Ca}^{2+}$ remaining after extraction of germlings differentiating on a polystyrene dish.

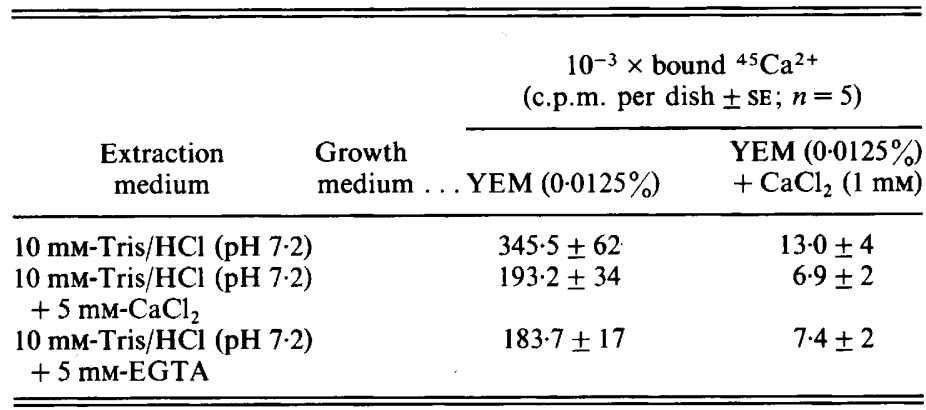

Table 3. ${ }^{45} \mathrm{Ca}^{2+}$ in fractions of Metarhizium mycelia

\begin{tabular}{lc}
\hline \hline \multicolumn{1}{c}{ Fraction } & $\begin{array}{c}10^{-3} \times{ }^{45} \mathrm{Ca}^{2+} \text { content } \\
\left.\text { (c.p.m. } \mathrm{ml}^{-1}\right)\end{array}$ \\
\hline Intact mycelia (100 mg wet wt) & 154 \\
$\begin{array}{l}\text { Protoplasts (derived from } 100 \mathrm{mg} \\
\text { wet wt of mycelia) }\end{array}$ & 82 \\
$\begin{array}{l}\text { Low speed supernatant }(15000 \mathrm{~g}) \\
\text { of protoplast lysate }\end{array}$ & 29 \\
$\begin{array}{l}\text { Mitochondrial pellet } \\
\text { High speed supernatant }(40000 \mathrm{~g}) \\
\text { of protoplast lysate }\end{array}$ & 65 \\
Plasma membrane pellet & $2 \cdot 6$ \\
\hline \hline
\end{tabular}

drial/vacuole and plasma membrane fractions and lack of radioactivity in the supernatants indicates that ${ }^{45} \mathrm{Ca}^{2+}$ was tightly bound to these structures.

Both mitochondria and vacuoles sequestered ${ }^{45} \mathrm{Ca}^{2+}$ in the presence of permeant precipitating anions in a process stimulated by MgATP and inhibited by DCCD, an inhibitor of $\mathrm{H}^{+}$-translocating ATPases (Table 4). Under the conditions of our assay, vacuoles took up ${ }^{45} \mathrm{Ca}^{2+}$ at a 25 -fold greater rate than mitochondria.

\section{The role of $\mathrm{Ca}^{2+}$ channels in differentiation}

The role of $\mathrm{Ca}^{2+}$ channels and the endoplasmic reticulum were studied using well-characterized inhibitors. Plasma membrane $\mathrm{Ca}^{2+}$ channel blockers (nifedipine or verapamil) at $50 \mu \mathrm{M}$ or specific antagonists of $\mathrm{Ca}^{2+}$ transport across endoplasmic reticulum [ryanodine $(50 \mu \mathrm{M})$, fluorescein isothiocyanate $(100 \mu \mathrm{M})$ and TMB-8 $(100 \mu \mathrm{M})]$ did not affect differentiation frequency. In fungi and other organisms, $\mathrm{Li}^{+}$ions ( $\leq 5 \mathrm{mM}$ ) specifically disrupt the phosphatidylinositol cycle which mediates the release of $\mathrm{Ca}^{2+}$ from the endoplasmic reticulum and 
Table 4. ${ }^{45} \mathrm{Ca}^{2+}$ uptake by mitochondria and vacuoles

\begin{tabular}{|c|c|c|}
\hline \multirow[b]{2}{*}{ Inhibitor } & \multicolumn{2}{|c|}{$\begin{array}{c}10^{-3} \times{ }^{45} \mathrm{Ca}^{2+} \text { uptake } \\
{\left[\text { c.p.m. }(\mu \mathrm{g} \text { protein })^{-1} \pm \mathrm{SE}\right]^{*}}\end{array}$} \\
\hline & Mitochondria & Vacuoles \\
\hline None & $3 \cdot 2 \pm 0 \cdot 4(100)$ & $78 \cdot 4 \pm 14.0(100)$ \\
\hline $\operatorname{DCCD}(0.01 \mathrm{mM})$ & $0.45 \pm 0.1(14)$ & $17.53 \pm 5.7(22)$ \\
\hline $\mathrm{Na}_{3} \mathrm{VO}_{4}(0.1 \mathrm{mM})$ & $2.94 \pm 0.4(92)$ & $69 \cdot 26 \pm 6 \cdot 3(90)$ \\
\hline$\left(-\mathrm{Mg}^{2+}\right) \dagger$ & $1.34 \pm 0.3(42)$ & $28 \cdot 20 \pm 8 \cdot 2(36)$ \\
\hline$(-\mathrm{ATP}) \dagger$ & $0.90 \pm 0.2(28)$ & $25 \cdot 54 \pm 5.4(33)$ \\
\hline
\end{tabular}

* Percentage values are given in parentheses.

$\dagger \mathrm{MgCl}$ or ATP were omitted from reaction mixtures.

activates protein kinase $\mathrm{C}$ (Hanson, 1989; Van Lookeren Campagne et al., 1988). High levels of $\mathrm{LiCl}(>20 \mathrm{~mm})$ were required to inhibit growth and differentiation of Metarhizium. At $10 \mathrm{~mm}$, differentiation frequency was reduced by only $9 \%$ from controls.

\section{Discussion}

The $\mathrm{Ca}^{2+}$ CTC membrane associated fluorescence in tip-growing systems and the stimulation of polar growth by $\mathrm{Ca}^{2+}$ has led to the conclusion that a tip-to-base $\mathrm{Ca}^{2+}$ gradient is involved specifically in apical extension (Jackson \& Heath, 1989; Picton \& Steer, 1983). The effects of $\mathrm{Br}-\mathrm{A} 23187$ demonstrate that tip growth and differentiation of appressoria in Metarhizium are also very sensitive to changes in the distribution of $\mathrm{Ca}^{2+}$ and perhaps $\mathrm{Mg}^{2+}$. Most studies to date have not tested $\mathrm{Mg}^{2+}$ even though the ionophore used (A23187) is less specific for $\mathrm{Ca}^{2+}$, as compared with $\mathrm{Mg}^{2+}$, than the brominated derivative (Br-A23187) used in this study (Deber et al., 1985). In Metarhizium the effects of $\mathrm{Mg}^{2+}$ may complement those of $\mathrm{Ca}^{2+}$ as its adenylate cyclase and the $\mathrm{Ca}^{2+}$ dependent kinases have a requirement for $\mathrm{Mg}^{2+}(\mathrm{St}$ Leger et al., 1990b) as does $\mathrm{Ca}^{2+}$ uptake by vacuoles.

Inhibition of germination by $\mathrm{Ca}^{2+}$ deprivation and the multiple emergence of broad and branched germ-tubes from conidia in the presence of $\mathrm{Br}-\mathrm{A} 23187$ indicates that while $\mathrm{Ca}^{2+}$ plays a fundamental role in tip growth, perhaps establishing the dominance of apical growth (Schmid \& Harold, 1988), it may not be involved directly in initiating polarity and formation of an apex. The effects of $\mathrm{Ca}^{2+}$ may be mediated by other components of the cell. The relative inability of $\mathrm{Ca}^{2+}$ in the absence of $\mathrm{Br}-\mathrm{A} 23187$ to affect cell growth argues against an important direct effect of $\mathrm{Ca}^{2+}$ on the Metarhizium cell wall. High concentrations of $\mathrm{Ca}^{2+}$, however, prevented lateral expansion of the apical tip, which, by analogy with plant systems (Demarty et al., 1984) may result from a stiffening of the cell wall produced by the accumulation of $\mathrm{Ca}^{2+}$. An increase in the intracellular $\mathrm{Ca}^{2+}$ concentration will stimulate the action of the $\mathrm{Ca}^{2+}$ and $\mathrm{Ca}^{2+} / \mathrm{CaM}$-dependent kinases which predominate in the cytoplasm of Metarhizium and consequently produce a biochemical cascade (St Leger et al., 1990b). Consistent with this, the localization of $\mathrm{CaM}$ at the poles of the conidium implies an important CaM-mediated role for $\mathrm{Ca}^{2+}$ in the manifestation of polarity as suggested in tipgrowing plant cells (Hauber et al., 1984). CaM-dependent phosphorylation events are crucial for the nutrient uptake and protein synthesis required for germination of Metarhizium conidia (St Leger et al., 1989c). In later stages, CaM might then help establish polarity by interacting with the cytoskeleton to regulate a variety of intracellular processes such as cytoplasmic streaming and vesicle transport. Inhibition by $\mathrm{CaM}$ antagonists of tip-growth and the production of bulbous swellings from conidia is consistent with such a role. We found no pharmacological evidence for phosphoinositide or protein kinase $\mathrm{C}$ signalling or a role for the endoplasmic reticulum as a $\mathrm{Ca}^{2+}$ store during germination and differentiation of Metarhizium.

There is an apparent contradiction in the roles $\mathrm{Ca}^{2+}$ may play during appressorium formation. The activation of a secretory process in animal and plant cells is generally linked to an increase in the cytoplasmic $\mathrm{Ca}^{2+}$ concentration. In Metarhizium too, secretion is a $\mathrm{Ca}^{2+}$ dependent process and germ-tube tips and appressoria are very active secretors of mucus and enzymes (Goettel et al., 1989; St Leger et al., 1987, 1989b). Also, appressorium formation was more sensitive to disruption of intracellular $\mathrm{Ca}^{2+}$ gradients than was polar growth. However, by analogy with other systems (Jackson \& Heath, 1989; Picton \& Steer, 1982) an increase in the cytoplasmic $\mathrm{Ca}^{2+}$ concentration would prevent the relaxation of the actin cytoskeleton necessary for lateral expansion of the apical tip. An obligatory role for actin in tip growth of Metarhizium and the transition to nonpolarized growth was shown by depletion of actin filaments with cytochalasin A (St Leger et al., 1990a). Also, consistent with this, increasing the $\mathrm{Ca}^{2+}$ concentration by ionophoresis stimulated polar growth at the expense of appressorial formation while endogenous reserves of $\mathrm{Ca}^{2+}$, originating from the conidium, are sufficient for differentiation. The ability of the mitochondria and vacuoles to sequester $\mathrm{Ca}^{2+}$ suggests that these organelles, which are particularly large and abundant in appressoria (Zacharuk, 1970; Goettel et al., 1989) may function to maintain localized cytoplasmic $\mathrm{Ca}^{2+}$ at the levels required for alterations in the cytoskeleton and other growth processes, as reported in plant systems (Picton \& Steer, 1985). Consistent with this, mutants of Neurospora crassa defective in the 
transport of $\mathrm{Ca}^{2+}$ into a vacuolar fraction are subject to inhibition by extracellular $\mathrm{Ca}^{2+}$ (Cornelius \& Nakashima, 1987). The sensitivity of $\mathrm{Ca}^{2+}$ uptake by Metarhizium vacuoles to ATP, $\mathrm{Mg}^{2+}$ and $\mathrm{DCCD}$ resembles reports for yeast vacuoles in which the driving force for uptake is a $\mathrm{pH}$ gradient produced by a $\mathrm{H}^{+}$translocating ATPase that uses MgATP as a substrate (Uchida et al., 1988). The presence of CaM- and other $\mathrm{Ca}^{2+-b i n d i n g ~ p r o t e i n s ~ i n ~ M e t a r h i z i u m ~ a p p r e s s o r i a ~ p r o-~}$ vides an additional energy-independent component of $\mathrm{Ca}^{2+}$ buffering in the cytoplasm. Enhanced exocytosis with low cytoplasmic levels of $\mathrm{Ca}^{2+}$ may be possible if the plasma membrane and bordering cell wall are a localized reservoir of $\mathrm{Ca}^{2+}$ (as suggested by the distribution of ${ }^{45} \mathrm{Ca}$ and also by CTC staining) and if the effects of the small localized changes in $\mathrm{Ca}^{2+}$ concentration that effect apical dominance are potentiated by another second messenger such as cAMP. This possibility was confirmed by the effects of cAMP when added to otherwise ineffective concentrations of $\mathrm{Br}-\mathrm{A} 23187$. In combination cAMP (or IBTX) and Br-A23187 generate an extra mitotic division in the conidia, reduce polar growth and stimulate secretion of mucus. cGMP had similar effects except that production of mucus was less. In some aspects, the morphological effects of cAMP in combination with $\mathrm{Br}-\mathrm{A} 23187$ mimic the formation of appressoria, notably the swelling of the cell with concomitant reduction in extension growth, enhanced Uvitex staining of the cell wall and enhanced mucus production. The results with Uvitex suggest that changes in cAMP concentration may have an effect on the organization of wall formation, which is fundamental to differentiation of Metarhizium (St Leger et al., 1990a). In contrast to our observations with Metarhizium, cAMP represses formation of side-branching in Neurospora crassa (Reissig \& Kinney, 1983). It is, however, possible that fluctuations in the relative concentrations of $\mathrm{Ca}^{2+}$ and CAMP are the controlling influence on morphology as high concentrations of ionophore or ionophore plus $\mathrm{Ca}^{2+}$ did not allow branching in the presence of cAMP.

The fluctuating rise in cAMP concentrations recorded during differentiation is circumstantial evidence that cAMP has a role in appressorium formation. These prolonged shifts, lasting hours, are unlike the transient responses previously recorded in Metarhizium (St Leger et al., 1990 b). They resemble, however, long-term changes which occur in several dimorphic fungi (e.g. Histoplasma capsulatum; Maresca \& Kobayashi, 1989). Better evidence for a role for cAMP in differentiation was provided by application of $\mathrm{H}-8$, previously shown to inhibit cAMP-sensitive phosphorylation at the plasma membrane and phosphorylation of a $27 \mathrm{kDa}$ cytoplasmic protein (St Leger et al., 1989c, 1990a). Cells whose differentiation was blocked with $\mathrm{H}-8$ produced little mucus and adhered poorly to the substrate. This suggests that cAMP-stimulated mucus secretion is responsible for adhesion. It is also possible that adhesion is a prerequisite for differentiation or that the mucus contains components required for signal reception. Together with our previous evidence that treatments which stress the fungi or depolarize the plasma membrane cause rapid increases in intracellular cAMP levels (St Leger et al., $1990 \mathrm{~b}$ ) these results suggest that cAMP may play a role in the mediation of externally determined differentiation processes.

This work was supported in part by a grant (89-37263-4463) from the USDA Competitive Research Grants Office.

\section{References}

Bowman, E. J. \& Bowman, B. J. (1988). Purification of vacuolar membrane, mitochondria and plasma membranes from Neurospora crassa and modes of discriminating among the different $\mathrm{H}^{+}$ATPases. Methods in Enzymology 157, 562-573.

BRADFORD, M. M. (1976). A rapid and sensitive method for the quantitation of microgram quantities of protein utilizing the principle of protein-dye binding. Analytical Biochemistry 72, 248254.

Butt, T. M., Hoch, H. C., Staples, R. C. \& St Leger, R. J. (1989). Use of fluorochromes in the study of fungal cytology and differentiation. Experimental Mycology 13, 303-320.

CAswell, A. H. (1979). Methods of measuring intracellular calcium. International Review of Cytology 56, 145-181.

CoRnelius, G. \& NaKashima, H. (1987). Vacuoles play a decisive role in calcium homeostasis in Neurospora crassa. Journal of General Microbiology 133, 2341-2347.

Deber, C. M., Tom-Kun, J., MaCK, E. \& Grinstein, S. (1985). BromoA23187: a nonfluorescent calcium ionophore for use with fluorescent probes. Analytical Biochemistry 146, 349-352.

Demarty, M., Morvan, C. \& Thellier, M. (1984). Calcium and the cell wall. Plant, Cell and Environment 7, 441-448.

GerisCH, G. (1987). Cyclic AMP and other signals controlling cell development and differentiation in Dictyostelium. Annual Review of Biochemistry 56, 853-879.

Goettel, M. S., St Leger, R. J., Rizzo, N. W., Staples, R. C. \& ROBERTS, D. W. (1989). Ultrastructural localization of a cuticledegrading protease produced by the entomopathogenic fungus Metarhizium anisopliae during penetration of host (Manduca sexta) cuticle. Journal of General Microbiology 134, 2233-2239.

Goettel, M. S., St Leger, R. J., Bhairi, S., Jung, M. K., OAKley, B. R., Roberts, D. W. \& Staples, R. C. (1990). Transformation of the entomopathogenic fungus Metarhizium anisopliae using the Aspergillus nidulans benA3 gene. Current Genetics 17, 129-132.

Hanson, B. A. (1989). The effects of lithium on the growth, morphology and biochemistry of Neurospora crassa. Program of the XV Fungal Genetics Conference, University of California, Los Angeles.

Hauber, I., Herth, W. \& Reiss, H. D. (1984). Calmodulin in tipgrowing cells, visualized by fluorescing calmodulin-binding phenothiazines. Planta 162, 33-39.

HidaKa, H. \& TANAKA, T. (1987). Transmembrane $\mathrm{Ca}^{2+}$ signalling and a new class of inhibitors. Methods in Enzymology 139, 570-582.

JACKSON, S. L. \& HEATH, I. B. (1989). Effects of exogenous calcium ions on tip growth, intracellular $\mathrm{Ca}^{2+}$ concentration and actin arrays in hyphae of the fungus Saprolegnia ferax. Experimental Mycology 13, 1-12. 
Maresca, B. \& Kobayashi, G. S. (1989). Dimorphism in Histoplasma capsulatum: a model for the study of cell differentiation in pathogenic fungi. Microbiological Reviews 53, 186-209.

Maruyama, K., Mikawa, T. \& Ebashi, S. (1984). Detection of calcium binding proteins by ${ }^{45} \mathrm{Ca}^{2+}$ autoradiography on nitrocellulose membrane after sodium dodecyl sulfate gel electrophoresis. Journal of Biochemistry 95, 511-519.

MCKerRaCher, L. J. \& Heath, I. B. (1987). Cytoplasmic migration and intracellular organelle movements during tip growth of fungal hyphae. Experimental Mycology 11, 79-100.

Picton, J. M. \& STEER, M. W. (1982). A model for the mechanism of tip extension in pollen tubes. Journal of Theoretical Biology 98, 15-20.

Picton, J. M. \& Steer, M. W. (1983). Evidence for the role of $\mathrm{Ca}^{2+}$ ions in tip extension in pollen tubes. Protoplasma 115, 11-17.

Picton, J. M. \& SteEr, M. W. (1985). The effects of ruthenium red, lanthanum, fluorescein isothiocyanate and trifluoperazine on vesicle transport, vesicle fusion and tip extension in pollen tubes. Planta 163, 20-26.

REISSIG, J. L. \& KINNEY, S. G. (1983). Calcium as a branching signal in Neurospora crassa. Journal of Bacteriology 154, 1397-1402.

Rothermel, J. D., Perillo, N. L., Marks, J. S. \& Parker Botelho L. M. (1984). Effects of the specific cAMP antagonist (Rp)Adenosine cyclic 3',5'-phosphorothioate, on the cAMP-dependent protein kinase-induced activity of hepatic glycogen phosphorylase and glycogen synthase. Journal of Biological Chemistry 259, 1529415300 .

SCHMID, J. \& HAROLD, F. M. (1988). Dual roles for calcium ions in apical growth of Neurospora crassa. Journal of General Microbiology 134, 2623-2631.

St Leger, R. J., COOPER, R. M. \& Charnley, A. K. (1987). Production of cuticle-degrading enzymes by the entomopathogen Metarhizium anisopliae during infection of cuticles from Calliphora vomitoria and Manduca sexta. Journal of General Microbiology 133, 1371-1382.

St Leger, R. J., Butt, T. M., Roberts, D. W. \& Staples, R. C. $(1989 a)$. Production in vitro of appressoria by the entomopathogenic fungus Metarhizium anisopliae. Experimental Mycology 13, 274-288.
St Leger, R. J., Butt, T. M. Staples, R. C. \& Roberts, D. W. $(1989 \mathrm{~b})$. Synthesis of proteins including a cuticle degrading protease during differentiation of the entomopathogenic fungus Metarhizium anisopliae. Experimental Mycology 13, 253-262.

St Leger, R. J., Roberts, D. W. \& Staples, R. C. (1989c). Calcium and calmodulin-mediated protein synthesis and protein phosphorylation during germination, growth and protein production by Metarhizium anisopliae. Journal of General Microbiology 135, 21412154.

St Leger, R. J., Roberts, D. W. \& Staples, R. C. (1989d). Novel GTP-binding proteins in plasma membranes of the fungus Metarhizium anisopliae. Biochemical and Biophysical Research Communications 164, 362-366.

St Leger, R. J., Roberts, D. W. \& Staples, R. C. (1990 a). A model to explain differentiation of appressoria by germlings of Metarhizium anisopliae. Journal of Invertebrate Pathology (in the Press).

St Leger, R. J., Laccetti, L. B., Staples, R. C. \& Roberts, D. W. $(1990 \mathrm{~b})$. Protein kinases in the entomopathogenic fungus Metarhizium anisopliae. Journal of General Microbiology 136, 1401-1411.

Takeuchi, Y., SChmid, J., Caldwell, J. H. \& Harold, T. M. (1988). Transcellular ion currents and extension of Neurospora crassa hyphae. Journal of Membrane Biology 101, 33-41.

UCHIDA, E., OHsumi, Y. \& ANRAKA, Y. (1988). Purification of yeast vacuolar membrane $\mathrm{H}^{+}$-ATPase and enzymological discrimination of three ATP-driven proton pumps in Saccharomyces cerevisiae. Methods in Enzymology 157, 544-562.

van Lookeren Campagne, M. M., Grneux, C., Van Eijk, R. \& Van HANSTERT, P. J. M. (1988). Two dephosphorylation pathways of inositol 1,4,5-triphosphate in Dictyostelium discoideum homogenates. Biochemical Journal 254, 343-350.

Wessels, J. G. H. (1986). Cell wall synthesis in apical hyphal growth International Review of Cytology 104, 37-79.

ZACHARUK, R. Y. (1970). Fine structure of the fungus Metarhizium anisopliae infecting three species of larval elateridae (coleoptera). II. Conidial germ tubes and appressoria. Journal of Invertebrate Pathology 15, 81-91. 